\title{
Raffles, the Naskah Kitab Hukum Manuscript and Social Engineering of the Inhabitants of Java in 1814
}

\author{
*HAZMIRULLAH \\ TITIN NURHAYATI MA'MUN \\ REIZA D DIENAPUTRA \\ Program Pascasarjana, Fakultas Ilmu Budaya, Universitas Padjadjaran, \\ Jalan Ir Soekarno KM 21 Jatinangor, Sumedang, Jawa Barat, Indonesia \\ *Correponding author: azmeer125@gmail.com
}

Published online: 15 April 2020

To cite this article: Hazmirullah, Titin Nurhayati Ma'mun and Reiza D Dienaputra. 2020. Raffles, the Naskah Kitab Hukum manuscript and social engineering of the inhabitants of Java in 1814. KEMANUSIAAN the Asian Journal of Humanities 27(1): 69-88. https://doi.org/10.21315/ kajh2020.27.1.4

To link to this article: https://doi.org/10.21315/kajh2020.27.1.4

\begin{abstract}
The Naskah Kitab Hukum manuscript issued by Thomas Stamford Raffles in 1814 is one of the important manuscripts in the history of a judicial system in Indonesia. The manuscript was published because Raffles, upon his early days of duty, noticed that the existing judicial system in Java was complicated and confusing, constituted in the formalities of the Roman law. This article presents a study of how the Naskah Kitab Hukum became a means of social engineering of the inhabitants of Java through at least three ways: (1) legislation process before the issuing of regulation, (2) accommodating the social cohesion of Java inhabitants into the regulation and (3) domestication of English legal terms which were not familiar to the Java inhabitants.
\end{abstract}

Keywords and phrases: Raffles, Naskah Kitab Hukum manuscript, social engineering, Java, history

\section{Introduction}

In 1814, the third year of the British interregnum period in Java, Raffles decided to issue a regulation of the police and judicial administration. The regulation which was written in Malay by using the Jawi script or Malay Arabic now became the part of The British Library collection, under the code Mss. Eur. D. 742/1, ff. 155-166. Authors obtained a digital "copy" through the website www. bl.uk and have asked for permission to use it as the object of this research orally from Annabel Teh Gallop, the Head of the South and South East Asia section at 
The British Library, London. We had met on two occasions, first at the 16th International Symposium of the Nationwide Manuscript Society (Manassa) at the National Library, Jakarta, which was held on 26th-29th September 2016. The second occasion was at International Seminar on Pernaskahan Nusantara at Sebelas Maret University, Surakarta, Central Java, which was held on 25th-26th September 2017. The British Library referred the manuscript as "Malay translation of Police and Judicial Regulations, signed and sealed by Raffles, Letnan Gubernur yang terhormat atas Pulau Jawa dan takluknya, written in Java, February 11th, 1814". The information was also confirmed by two lines of writing which is "Malay Translation of the Police and Judicial Regulations" on page 166 verso. Hereinafter, we call the regulation as the Naskah Kitab Hukum (1814a) manuscript, in accordance with the text which had been written in the third line, "Bahwa dari sebab Tuan Letnan Gurnadur Yang Terhormat dalam Perhimpunan Raad telah timbang-menimbang wajib menetapkan satu kitab hukum yang betul dan adil...".

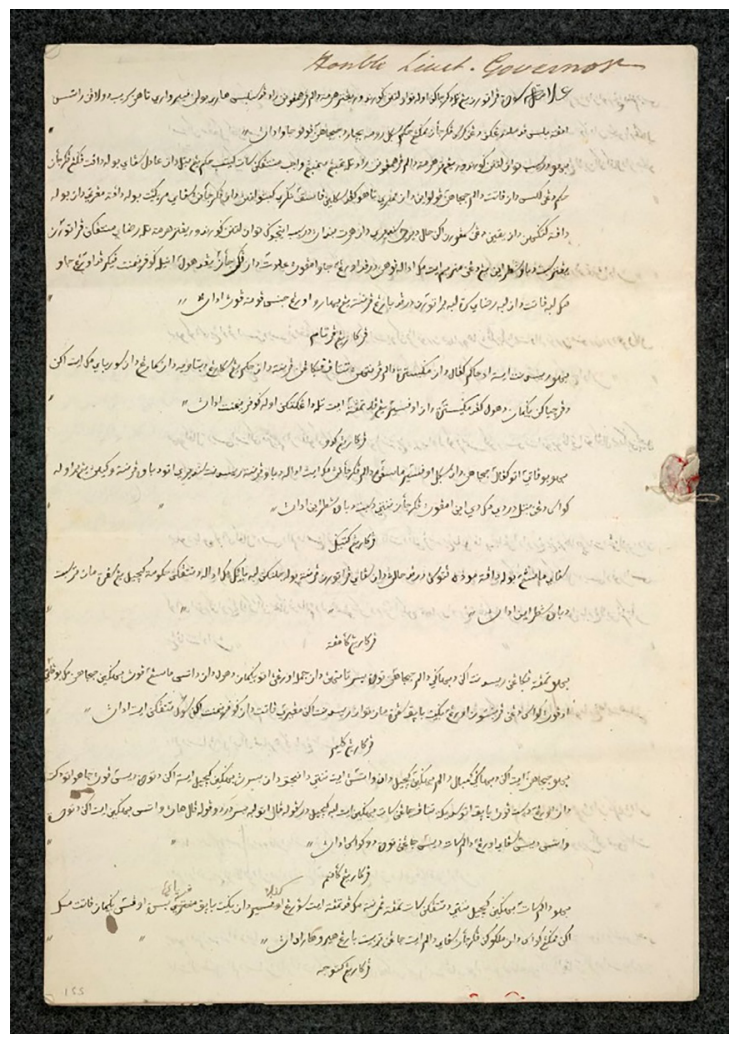

Figure 1. The front page of the Naskah Kitab Hukum manuscript Source: The British Library collection, retrieved from http://www.bl.uk/manuscripts/Viewer.aspx?ref=mss_eur_d742!1_f155r 
Previously, the regulation was reviewed by Hazmirullah and Ma'mun (2018) in a book chapter entitled "Naskah Kitab Hukum Raffles: Sebabak Sejarah Sistem Peradilan di Nusantara". In the article, the authors examined the regulation by the codicological approach. This study revealed its uniqueness related to linguistic aspects, including the customised terms that were intended to make the regulation more familiar to the inhabitants of Java as the subject of law. They also revealed two matters that were governed by the regulation, which are: (1) the structure of the judiciary and (2) the duties and functions of the judicial institutions (and their officials). Furthermore, they put the contents of the regulation on the history of the judicial system since the Vereenigde Oost-Indische Compagnie (VOC) period to Daendels. They concluded that the publication of the Naskah Kitab Hukum manuscript was one proof that Raffles took fundamental action in the field of justice. It made the prevailing of the judicial system, especially in Java and its dependencies, obtained a different style than the ones that existed from the reign VOC until Daendels. Nevertheless, Raffles did not divide the holders of executive power with the holders of judicial power.

\section{History}

The British troops landed in Java on 4th August 1811 without opposition at Cilincing, a point on the coast 10 or 12 miles east of Batavia. Six days later (on 10th August 1811), they occupied Weltevreeden, the centre of Batavia without firing a shot. Later, on 26th August 1811, they captured Meester Cornelis, a strong fortress located seven miles south of Batavia, on the line of hills (Boulger 1897, 128, 130; Thorn 2004, 17, 30-31, 56). However, the British effectively controlled Java on 18th September 1811, after Governor-General of Franco-Dutch, Jan Willem Janssens, signed a capitulation in Tuntang Village, Salatiga, Central Java. After Governor-General of British East India Company, Lord Minto, left Java on 19th October 1811, the duties and responsibilities for administration in Java were handed over to Raffles; actually, he was appointed as the Lieutenant-Governor of Java and Its Dependencies on 11th September 1811 (Boulger 1897, 133, 136).

Raffles already had considerable knowledge about Java. In October 1810, Minto appointed Raffles as his agent to the Malay States; a task that was a part of Minto's plan to occupy Java, after British occupation of Mauritius and Bourbon Island (now called Reunion Island). Based on the reports that he had received several months before the occupation of Java, Raffles had concluded that the VOC, while in administration in Java, had carried out a very vicious system which caused suffering to the Javanese people. He felt obligated to free them from the suffering because, as he stated, "that it would have been unworthy of the British character to have remained quiet spectators of abuses, and to have admitted the continuance of feudal barbarism" (Raffles 1814b, 4). 
During the remaining five weeks which he spent in Java, from Janssens' surrender to his departure to Bengal, Minto visited many areas in Java and gathered a lot of information from the local authorities. He concluded that one of the cruel policies that had taken place since the VOC administration had to be abolished as soon as possible. The policy was forced deliveries and services. According to Bastin (1958, 16-18), on the day prior to his departure for Bengal, Minto met with Raffles. He stated that radical changes in various policies must be taken seriously. Revenue arrangement should be the highest priority of the British government. He cautioned Raffles that the radical changes should not be made when policies were not yet mature.

Raffles responded to Minto's instruction by forming a committee, known as MacKenzie Committee, on 22th October 1811. Later, on 14th June 1813, based on the recommendations of the committee, Raffles submitted a proposal to the Board Directors of East India Company (EIC) regarding the amended system that would be applied in Java. As the foundation for the proposal, he proposed changes to three matters. The first one was the entire abolishment of all forced delivery of produce at inadequate rates and of all feudal services. Second matter was on the assumption, on the part of the government, of the immediate superintendence of the lands. The revenues and rents thereof were collected without the intervention of the regents (the bupatis). Third matter was about the renting out of the lands as large or small estates, according to local circumstances, on leases for the moderate term (Raffles 1814b, 261). Raffles considered that all land in Java was an important and superior object for profit; so that the ownership of it must be taken over by the government. However, the government must first ensure that the abolition of forced deliveries and services was going well and was not causing turmoil throughout the country. Raffles estimated that the only difficulty which occurred was the mode in which the regent shall be provided for, so as to prevent their services from being lost to the public, or themselves from being thrown out of employ. Therefore, he suggested that the regents and their subordinate officers should be employed exclusively in the police - and judicial - duties because their interference would become useless, and even burdensome, in the collection of the revenue (Raffles 1814b, 263).

\section{Raffles' Influence}

The regulation was issued on the basis of his desire to ensure that judicial process, especially towards indigenous people of Java, was fairly implemented. He used it as a guarantee for the British government to maximise the revenue collection from Java. Raffles explained, as written in his report to Lord Minto, that upon his early 
days of duty, the existing judicial system was complicated and confusing. There were courts in the principal towns of Java, but these courts were constituted in all of the troublesome formalities of the Roman law (Raffles 1814b, 156). Meanwhile, in the opening section, it was stated that the Naskah Kitab Hukum manuscript is written - then published and disseminated - for two purposes: first, "to give to all ranks of people (in Java) a due knowledge of their rights and duties" and second, "to ensure to them an enjoyment of the most perfect security of person and property".

\section{Social Engineering}

Based on the background of issuing the Kitab Hukum and its objectives, we argue that Raffles wanted to carry out social engineering on the indigenous people of Java while social engineering is the centre of sociological jurisprudence theory. Social engineering was designed as an effort to create a balance and harmony from various conflicts of interest in society. It was based on the idea that law is a tool that can be used to shape society and regulate the human behaviour.

\section{Sociological Jurisprudence}

Sociological jurisprudence is a part of the sociological law school which was widely used by legal experts since the beginning of the 20th century. That school, according to Soekanto $(2016,42)$, was pioneered by an Austrian legal expert, Eugen Ehrlich (1826-1922), through his famous work entitled Fundamental Principles of the Sociology of Law (1913). Ehrlich's teaching is based on the distinction of positive law and living law. According to him, the positive law will only be effective if it is in harmony with the laws that live in society. Therefore, the centre of legal development stands on the society itself, not in the legislative bodies, judicial bodies' decisions, or in law. However, the order in society is based on the regulations imposed by the state.

Subsequently, sociological jurisprudence developed and became popular in the United States, mainly because of the dedication of Roscoe Pound (1870-1964). Pound became a recognised leader of the sociological school of thought in the United States (US) for more than half a century. He understands the law, by nature, in three meanings. First, a highly specialised form of social control in a developed politically organised society obtained by the application of a force of that society. Second, a body of authoritative guides to decision. Third, a judicial and administrative process, in which the guides to a decision are developed and applied by the authoritative techniques, in the light of received authoritative 
ideas. Therefore, he defined law as experience organised and developed by reason, authoritatively promulgated by the law-making or law-declaring organs of a politically organised society and backed by the force of that society (Gardner 1961, 12; McManaman 1958, 13).

The legal experts of this school of thought always focused on the working of law rather than the abstract content of legal products. They argued that the law should be studied in the context of action, not merely based on a textbook, so that they concentrate on legal studies in relation to society. According to Pound (1912, 516), the adherents of sociological schools emphasise the concern for social goals provided by law, not on sanctions. One key feature of this approach is reviewing the effect of law and society on each other; it is because the law is considered as an instrument of social progress. In other words, as mentioned by Singh (2016), sociological jurisprudence is a functional legal study applied to concrete social problems in order to make law an effective means of social control to harmonise conflicts of interest between the individuals in society.

Social engineering, as we stated before, was designed as an effort to create a balance and harmony from various conflicts of interest in society. It was based on the idea that the law is a tool that can be used to shape society and regulate the human behaviour. Therefore, Pound through this theory made the law as a dynamic medium, in which it is capable to accommodate social cohesion, using a variety of ways (techniques) that allow all the aspirations of society to be fulfilled and accomplished. For this purpose, he said, it is necessary to identify and protect the interests of the community by applying multi-faceted and multi-staged approaches. That is what he calls the theory of interest. Pound (1912) stated that interests are "demands and wills that human beings both individually or in groups seek to acquire it". Such interests shall be legally protected by granting them the status of legal rights. Therefore, the principal purpose of the social engineering is "to construct as efficient a structure of society as possible which requires the satisfaction of wants with the minimum of friction and waste resources. It means law should work for balancing for the competion of interest within the society for the greatest benefit" (Wacks 2012, 164).

\section{Findings and Discussions}

In the context of issuing the Kitab Hukum, social engineering carried out by Raffles to the indigenous people of Java could be seen to effect three matters: first, legislation process before the issuing of regulation, second, accommodating the social cohesion of Java inhabitants into the regulation and third, domestication of legal terms in English which were not familiar with the Java inhabitants. 


\section{The Contents of the Naskah Kitab Hukum Manuscript}

The Naskah Kitab Hukum which consists of 173 articles, in general, governs two matters: first, the structure of the judiciary and second, the duties and functions of the judicial institutions (and their officials). Nevertheless, the regulation did not divide the duties between the executive and judicial power holders as in Indonesia today. A resident, for example, in addition to performing executive duties (governmental), also carried out judicial duties as a judge (head of court). It was also applied to officials below him, namely the regents and the heads of division.

Actually, the Naskah Kitab Hukum manuscript does not directly address the judicial system, as well as the main duties and functions of the judicial institution.

\section{Article 1 to 6: General provisions}

This related to the distribution of power in stages; the resident, the bupati (kepala jajahan; head of district), the kepala bahagian kecil (head of division), to the kepala kampung (head of the village). It explained that every residency shall be divided into a number of districts that will be adjusted to the size of territory, population, or former customs. Furthermore, every district shall be divided into a number of divisions (in Indonesia now, it is equivalent to the kecamatan).

\section{Article 7 until 24: 18 articles}

The Naskah Kitab Hukum manuscript then explains the main tasks and functions of the regional officials in stages, starting from the head of the village (with various titles of it, such as petinggi, bekel, lurah, kuwu and mandor), for maintaining security and public order. The task was attached to the heads of the village and the police officers. The heads of the village should receive and carry into execution all orders from the government - which are lowered in stages from the governor to the residents, bupatis, and heads of divisions - and disseminate them to the public. Furthermore, they should be responsible for the security and regional peace. The heads of the village were also directed to keep a register of all individuals under their authority, describing the name, age, country, occupation, size and appearance of each individual, with any other remarks that may be deemed necessary. These records will be drawn up every six months. Moreover, they - along with the police officers - are authorised to apprehend any individuals that have done criminality (accompanied by evidence or complaints). Finally, the heads of the village have the right to receive rewards of a certain portion of land and guaranteed protection from the government. 


\section{Article 25 until 57: 33 articles}

These articles cover the main duties and functions of the heads of division. In addition to being responsible for administrative and police affairs, every head of division also has judiciary power. Article 47, for example, states that the head of divisions - with mantri and other helpers - must be at the paseban (open space) at the police station, at least once a week, to examine and resolve cases occurring in their respective territory. But, their authority is limited to petty cases, such as trespassing, nuisance, solving the unfair distribution of water and other such minor grievances of usual occurrence in the village. They shall be empowered to hear and determine on civil cases that may be referred to them, provided that the amount at issue does not exceed 20 rupiahs and they also authorised to fine (that does not exceed 10 rupiahs), but not to catch or imprison people.

\section{Article 58 until 83: 26 articles}

These articles define the main duties and functions of the bupati (the heads of a district). At the district level, the government had established a regular court headed by the bupati (regent). If he was unable to do so, he might hand over the duty to the patih. Nevertheless, the district courts were only authorised to handle civil cases with no less than 20 rupiahs and no more than 50 rupiahs. Meanwhile, the handling of all criminal cases, except for a small portion submitted to the head of the division, was the authority of the Resident Court (Raad Residen).

\section{Article 84 to 150: 67 articles}

These articles discuss governing the main duties and functions of the residents. In trial practices, the resident acted as a single judge. He was also permitted to submit duties to the assistant-resident if he was absent. The bupatis (or patihs) must attend the court sessions in the Resident Court to expound their opinions and/or information as required. The head jaksa and the penghulu were also obligated to attend and were in charge of explaining the applicable laws, customs, and taking testimony from the witnesses. While the jaksa of the district, acted as public prosecutors. In addition, the trial was also attended by a number of other officials, in accordance with the customs in that area.

The Resident Court was authorised to handle civil and criminal cases, both original and appeal cases from the previous court. However, for civil cases, the value should not be less than 50 rupiahs. As for criminal cases, the Resident Court can only handle criminal cases that do not cause a death penalty. Any criminal acts that caused a death penalty should be handled by the Court of Circuit (Raad 
Sambang or Raad Keliling). The resident only had the right to charge the suspect of imprisonment. The rules in the Naskah Kitab Hukum also require the resident to be responsible for the management of the prison. At least once in every two weeks, the residents must visit it to monitor directly (and also to receive reports) on the healthcare services for prison inmates and the warden's behaviours. As regards to health care, the resident must bring in a doctor to check the prisoners at least once a day. The doctor must submit a monthly report to the resident.

\section{Article 151 to 171: 21 articles}

These govern the basic tasks and functions of the Court of Circuit in 21 articles. In fact, that court was not a regular one, but it was only held at least four times a year. The court leader is actually a member of Raad van Justitie (Court of Justice) in Batavia, Semarang, or Surabaya. One of them is assigned to make a circuit through the districts that are under the Raad van Justitie. Trials are then held at the place that is usually used by the residents. Therefore, the residents must find other places to hold their Residential Court during the Raad Sambang court sessions.

One thing that distinguishes Raad Sambang with other courts is the presence of another party called "the jury". The manuscript mentions that the jury shall consist of five people. The persons composing this jury ought to be as near on an equality, as to rank in life, with the prisoner as possible. But, no one under the rank of a head of a village shall be competent to act as a juryman, as persons below that office. Any persons in the very lower orders of life cannot be or supposed to possess independence or knowledge sufficient to qualify them to execute justly the duties of the situation. The person senior in dignity among the juryman shall be appointed to act as foreman and for this purpose, it may be as well that one of higher rank than the other four should be always selected in the first nomination of the jury. It is also stated that both the prosecutor and the prisoner have the right to accept or reject a jury member, as in the English court. In trial practices, Raffles - as Lieutenant-Governor Java and Its Dependencies - became the final decision maker, especially for two matters. First, whenever the opinions of the Penghulu and the Jaksa shall be in opposition to that of the head of court or second, in which the punishment of the crime shall amount to imprisonment or penal transportation for life.

\section{Legislation Process}

Before issuing the new regulations, Raffles had first collected information both from colonial officials and indigenous figures. He called on several residents to furnish as accurate an account as was in their power, including the mode of carrying 
on the duties of police and judicial as it existed among the natives. Furthermore, Raffles consulted it with the most intelligent native authorities on the subject. He explained, "I was enabled to collect very considerable information...put me in possession of materials, quite sufficient to form the ground-work of a general regulation on the subject" (Raffles 1814b, 162).

Raffles did visit areas on Java often. In December 1811, three months after serving as Lieutenant-Governor, he visited the Yogyakarta Sultanate "to establish relations between the two governments in an agreement". In May 1812, he was in Cirebon (Thorn 2004, 122, 165). Four months later, Raffles visited the Eastern Districts of Java (Raffles 1814b, 28). He also received reports from David Hopkins and John Crawfurd. At the time, Hopkins assumed the position of Commissioner for Income Revenue at the Eastern Districts of Java, while Crawfurd served as Resident of Yogyakarta. However, in his report for Lord Minto, Raffles only quoted on Hopkins' report. It was stated that the inhabitants of Java indeed had legal rules which were considered very good. They combined customs inherited by ancestors with Islamic values, a religion that was later present. However, none of those rules are enforced "nationally".

It is such conditions that made Raffles feel the need to issue regulations that can be used for the citizens in Java Island as well as perfecting the rules that had been applied. You see, without improvements of the rules regarding the judiciary and the police system, all changes that are intended to support the industry while abolishing oppression and abusive actions will be futile (Raffles 1830, 320-321). Moreover, as we stated before, Raffles mentioned that upon his early days of duty, the existing judicial system was complicated and confusing. There were courts in the principal towns of Java, but these were constituted in all the troublesome formalities of the Roman law. There were also provincial courts in other places, called landraads, but the native laws were left to take its course, with all its barbarities and tortures. Therefore, it was according to that fact, that Raffles felt the need to lead the arrangements taken for the establishment of a good and efficient police force and the full and impartial administration of justice throughout Java. It was intended to guide government officials in performing their duties while protecting people from unfair treatment.

\section{Accommodating the Social Cohesion}

In September 1812, Raffles visited the Eastern Districts of Java and there, he felt the natural life of society because the European authority had not interfered and the influence of the Islamic government was scarcely felt. He also found two positive customs of which he adopted to the Police and Judicial Regulation. 
The first custom is the election of the chief by themselves, while the second is to keep regular nightly watches and patrols (ronda) preventing theft. Later on, Raffles also found similar customs in Jepara, Juwana, Sunda districts of Cirebon and Tegal. Therefore, Raffles $(1830,319)$ concludes that:

Each village has in itself the materials of a good police, and that a right of choosing their chiefs gives to the people a considerable share of real liberty. This right of election in the inhabitants of the village, as before observed, would appear at one time to have been general throughout the island.

Raffles then entered these two positive customs into the Naskah Kitab Hukum manuscript. The provision about the election of a chief is written in Article 7 while about patrols in Article 31. Raffles, by referring Hopkins' report, also stated that the inhabitants of Java had very good legal rules, the result of a combination of customary laws inherited by ancestors with the Islamic values. No wonder if Raffles then accommodated the involvement of penghulu, as the expert of Islamic and customary laws, in the judicial process. There are 10 articles in the Naskah Kitab Hukum manuscript that had governed the function and position of penghulu, which are three articles (i.e. Article 65, 66 and 67) for the Regency Court, six articles (i.e. Article 88, 90, 105, 106, 107 and 125) for the Residency Court and one article (Article 165) for the Court of Circuit (Raad Sambang).

Basically, the penghulu must answer all questions submitted by the judge or the head of the court. He must explain in detail the case based on legal rules - both those originating from Islamic law and the usage of community - that have been written, acknowledged and agreed to become customary since a long time ago. For the Regency Court, if his opinions concur with that of the head of the court, the case can be decided immediately. But if the penghulu's opinions are at variance, the bupati shall refer the case, with the several reasons detailed which have influenced each opinion, to the resident. For the Residency Court, the sentence must immediately be decided if the penghulu's opinions are in accordance with the resident and in which the punishment is not too heavy (such as imprisonment or transportation for life). If there is a difference of opinions or in which the punishment is too heavy, the resident must transmit the case to the government. The decision must be delayed until he receives the orders from the Lieutenant-Governor. Meanwhile, for the Court of Circuit, there is a provision that the judge must ignore all indigenous legal rules as may be expounded by the penghulu and jaksa. He must only consider the colonial law, as to be applied in Java, for his decision so that the law could fulfil the acknowledged principles of substantial justice. 
The description above proves that Raffles issued the Naskah Kitab Hukum manuscript as a means to form society as well as regulating human behaviour by first considering the various interests in it. Moreover, according to Day (1904, 195), Raffles succeeded in implementing a more efficient judicial system on Java and in establishing principles so as to establish a judicial relationship with the indigenous people. It was the fruit of Raffles' hard work in gathering information about the original customs, especially with regard to the judicial system. He also succeeded in inducing the indigenous people to hand all cases to the courts under European influence.

\section{Domesticating the Unfamiliar English Terms}

Raffles' desire to make the Naskah Kitab Hukum manuscript as a means of social engineering towards the inhabitants of Java could also be seen from his command on translating the regulation text from English into Javanese and Malay. This command had written in Article 173 of the regulation. However, so far, we only found the "original text" in the Substance of a Minute Recorded by The Honourable Thomas Stamford Raffles, Lieutenant-Governor of Java and Its Dependencies, on the 11th February 1814: On the Introduction of an Improved System of Internal Management and the Establishment of a Land Rental on the Island of Java (1814b) and in History of Java (1830). Meanwhile, unfortunately, we have not managed to find the translation in Javanese version.

We have compared the original text in English with the translation in Malay and have found interesting fact that the writer, or rather the translator, did not only translate English as a source text into Malay. He also replaced many terms into Malay as a target text which, perhaps, were more familiar to the Javanese people than in English terms (Hazmirullah and Ma'mun 2018, 12-13). Most likely, it was intended that the indigenous people of Java, as the subjects of law, genuinely understood the various rules contained in the regulation.

In translation theory, it was called domestication, a term which had introduced by Venuti (1995). Domestication is the translation strategy in which a transparent, fluent style is adopted in order to minimize the strangeness of the foreign text for target languages readers (Shuttleworth and Cowie 2014, 43-44). In this article, however, we only discuss three words in the Naskah Kitab Hukum as a case study. 


\section{The word pal}

First attention is drawn to the provisions regarding the extent of a division. In Malay version of the Naskah Kitab Hukum manuscript, the word "division" is translated as bahagian kecil. De Klein (1931) preferred to use the word cutak for this area. Division, bahagian kecil or cutak is an area that is a level below the district and it consists of several villages. In Indonesia now, the area is called kecamatan.

In the example shown in Table 1, we can see that the area unit which in English is called "square miles" is converted to pal, a loan-word from the Dutch language (paal). In the Naskah Kitab Hukum, this word only appears once, namely in Article 5 which regulates the area of each division. These two terms actually are different types. Square miles is a large measure while paal is a long measure. But, paal is a term which was friendlier for the indigenous people of Java in the second decade of the 19th century. Even until now, it is still used to mention places. It refers to the fact that the inhabitants of Java had always been built settlements linearly. At the first time, they always built settlements which elongated in the watershed, as discovered by early VOC explorers. At the time, the settlements formed were still small in size and population, with locations that were far apart. Nevertheless, in the watershed, there was a fairly heavy economic traffic (Breman 2014, 28, 55).

Table 1. The domestication of pal

\begin{tabular}{|c|c|}
\hline Source text (English) & Target text (Malay) \\
\hline $\mathrm{V}$ & Derkara yang Kelima \\
\hline $\begin{array}{l}\text { These Districts, again, shall be subdivided into } \\
\text { divisions, the extent and limits of each of which will } \\
\text { be clearly marked out and made known. Their size } \\
\text { must, of course, entirely depend on the greater or less } \\
\text { propinquity of the villages they contain, and on the } \\
\text { more or less numerous population by which these are } \\
\text { inhabited; but, generally speaking, no Division shall be } \\
\text { less than ten, or more than twenty square miles in extent. } \\
\text { It must also be observed, that the limits of the division } \\
\text { follow those of the villages; it being quite contrary to } \\
\text { a system of good police, that inhabitants of the same } \\
\text { place should be subject to different authorities. }\end{array}$ & $\begin{array}{l}\text { Bahwa jajahan2 itu akan dibahagi } \\
\text { kembali dalam bahagian2 kecil dan } \\
\text { watasnya itu nanti diunjuk. Dan } \\
\text { besarnya bahagian kecil itu akan } \\
\text { diturut desa2 punya jahu atau dekat, } \\
\text { dan orang2 di situ punya banyak atau } \\
\text { sedikit. Tetapi jangan satu bahagian } \\
\text { itu lebih kecil dari sepuluh pal atau } \\
\text { lebih besar dari dua puluh pal. Hanya } \\
\text { watas bahagian itu akan diturut watas } \\
\text { desa2 supaya orang2 dalam satu } \\
\text { desa2 jangan turut dua kuasa adanya. }\end{array}$ \\
\hline
\end{tabular}

Later on, the establishment of de Groote postweg changed economic conditions and life of the Javanese inhabitants on a large scale. It was in line with the existence of land transportation between the eastern and western regions of Java, the emergence of mobility in the farmer communities, and the commercialisation of crops. 
The establishment of the road also created the most important social group, namely the group of an intermediary trader (Lombard 2008, 74, 139). Since then, the people built settlements which are elongated in the road, no longer in the watersheds.

Isnaeni (2015), by citing Djoko Marihandono, a historian of Indonesia University, whom he had interviewed, stated that Daendels affixed a mark with a paal unit for each road segment that was completed. Therefore, many regions crossed by de Groote postweg have names with the prefix "Pal", i.e. Pal Merah, Pal Meriam and Pal Sigunung. In a number of regions in Indonesia, the conversion of pal are varies. According to Sastrodinomo (2009), 1 paal in Java is equal to 1,507 metres, while in Sumatra 1,852 metres. The Kamus Besar Bahasa Indonesia contains a pal entry which means "a milestone as a mark of distance, between one milestone and another $1.5 \mathrm{~km}$ ". This information is in line with Toer $(2005,24)$ who stated that Daendels planted the milestone (paal) as a mark every time the road that was built reached a length of 150,960 metres. It opens up the possibility that $1 \mathrm{pal}$ is actually not a distance between two milestones, but 10 milestones.

\section{The word sejumat}

Another interesting word to be discussed in the Malay version of the Naskah Kitab Hukum manuscript is sejumat. Apparently, this word was used to translate the English word "a week". See Table 2 as follows.

Table 2. The domestication of sejumat

\begin{tabular}{|c|c|}
\hline Source text (English) & Target text (Malay) \\
\hline LXXV & Perkara yang Ketujuh Puluh Lima \\
\hline $\begin{array}{l}\text { This complaint being filed, a copy of it } \\
\text { shall be sent to the person complained } \\
\text { of, with an order to answer it at most } \\
\text { within a week; and on receipt of this } \\
\text { answer, notice shall be given on what } \\
\text { day (at farthest a week from the time } \\
\text { of the receipt) the cause will be tried. } \\
\text { Such witnesses as are necessary will be } \\
\text { summoned; and on the day prescribed, } \\
\text { the complaint and answer being read, } \\
\text { and evidence being taken, the Court } \\
\text { shall give its decision. }\end{array}$ & $\begin{array}{l}\text { Jikalau pengaduan itu telah ditulis, maka nanti } \\
\text { dikirimkan satu salinan dari itu kepada orang yang } \\
\text { atasnya sudah dibawa pengaduan, dengan perintah } \\
\text { pada menyahuti itu sekurang2nya dalam sejumat } \\
\text { lamanya. Dan setelah sudah diterima jawab itu, } \\
\text { maka nanti diberi tahu apa hari, sekurang2nya se- } \\
\text { jumat di belakang keterimaan itu, maka bicara itu } \\
\text { akan diputuskan dan dipanggil kepada saksi2 yang } \\
\text { wajib. Dan pada hari yang tersebut setelah sudah } \\
\text { dibaca pengaduan2 dan sudah dipanggil kepada } \\
\text { saksi2, maka kedudukan akan memputuskan bicara } \\
\text { itu adanya. }\end{array}$ \\
\hline
\end{tabular}


The example in the table above was obtained from Article 75. In the Naskah Kitab Hukum manuscript, the word sejumat is written seven times. In addition to Article 75, it is also contained in Articles 67, 80, 91, 97 and 101. The domestication of this word was adjusted to the working days in Java at that time. Concerning this, Lombard (2008, 153-154) stated that by 1910, Djawi Kanda, a newspaper in Surakarta (Central Java, Indonesia), made a fairly reasonable note that given that there was a calm day, when it was accepted by everyone. It should be more natural if in Nusantara where millions of Muslims had lived there and a few Christians, a quiet day falls on Friday, not Sunday.

We have found that the word sejumat has been used at least in the 17th century. The evidence concerning this could be seen in the "friendship contract" between the Cirebon Sultanate and VOC signed on 4th December 1685. In Article 10 of this contract, it was stated that "...prakara witjara iku, pingkalih sadjumangat, amitjarakakèn, ing dina Rèbo sapisan dina A(h)ad sapisan, ing a(l)un-a(l)unan masigit agung iku lan ěnggoning kuna-kuna, amitjarakakěn, sakațahing prakawis, titi" (Brandes 1894, 469).

\section{The word bicara}

Subsequently, we discuss the word bicara which apparently had not only used to translate one English word but many words, as shown in the following Table 3.

Table 3. The domestication of bicara

\begin{tabular}{|c|c|}
\hline Source text (English) & Target text (Malay) \\
\hline XXXVI & Perkara yang Ketiga Puluh Enam \\
\hline $\begin{array}{l}\text { They will then, with this statement } \\
\text { accompanying, forward, under a sufficient } \\
\text { guard, the prisoner or prisoners, together } \\
\text { with the persons complaining or aggrieved, } \\
\text { and the witnesses of the facts, towards the } \\
\text { chief town of the district where the Bopati } \\
\text { resides. }\end{array}$ & $\begin{array}{l}\text { Mereka itu akan kirimkan orang2 yang terbelenggu } \\
\text { serta dengan surat bepertahukan dan dengan jaga } 2 \\
\text { yang keras ke hulu negeri jajahan atau kabupaten } \\
\text { di mana bupati tinggal bersama2 dengan orang } 2 \\
\text { yang mengadu dan yang membuat salah beserta } \\
\text { dengan saksi2 daripada bicara itu adanya. }\end{array}$ \\
\hline
\end{tabular}


Table 3. (Continued)

Source text (English)
LII
But the complaint having been given in,
the person complained of, if not present,
shall be summoned to appear by the next
day of sitting, when the cause shall be
heard and decided on without delay. In
failure of attendance on the part of the
plaintiff, the case shall be dismissed; on
the part of the defendant, the cause shall
be proceeded with ex parte. The sentence,
whatever it may be, shall be carried into
execution by means of the authority vested
in the Heads of Villages.

\section{CXVIII}

On the decision of the suit, a fee of two Rupees from the gainer, and of one from the loser of it, shall be received; and costs, at the rate of ten per cent on the amount of the sentence, being the custom of the country, shall be levied from the party against whom the decision has been given.

\section{CXXXV}

It must be observed, that in all causes which come into the Courts, the respective parties in them shall plead in their own behalf. It not having been heretofore usual to employ Vakeels, or native lawyers, for this purpose, no persons of this description shall be admitted. And it is trusted, that litigation will be considerably reduced and discouraged by this measure, as the trouble of it will then fall heavily and entirely on the principals themselves; that class of people not being allowed to exist, who, as deriving from litigation their sole subsistence, may fairly and without invidiousness, be considered as having some interest in increasing the business of the Courts.
Target text (Malay)

Perkara yang Kelima Puluh Dua

Tetapi jikalau telah dibawa masuk pengaduan2, maka kepada orang yang sudah kenah pengadu2an, jikalau ia tiada hadir, maka nanti dipanggil supaya datang menghadap dengan bermula kali kepada tempat kedudukan. Maka kemudian nanti diperiksa dan diselesaikan bicara itu dengan tiada bertangguh. Dan jikalau orang yang telah membawa pengaduan tiada menghadap, maka bicara itu akan dipegang sudah habis. Tetapi daripada pihak orang yang terbelenggu, maka bicara itu akan dijalankan atau dihambatkan. Dan surat putusan bagaimana juga itu, maka akan dilakukan oleh daya kuasa kepala2 desa adanya.

Perkara yang (Ke)seratus Delapan Belas

Dengan memputuskan bicara nanti diambil bea dua rupiah dari yang untung dan satu rupiah dari yang alah dan belanja2 akan sepuluh persent atas jumlah surat putusan maka nanti dipungut daripada orang yang alah bicara turut adat negeri adanya.

\section{Perkara yang (Ke)seratus Tiga Puluh Lima}

Pada hal segala bicara yang dibawa pada landrad atau tempat periksaan bupati, maka orang 2 yang lawan bicara tadapat tiada akan melawan sendiri bicaranya dan tiada boleh ia memakai pada itu barang wakil2nya sebab itu tiada biasa atau beradat pada dahulu2. Maka kepada orang2 itu akan tiada diluluskan sebab dirasa bahwa oleh perbuatan itu, maka bicara itu jadi kurang, dan segala susah, dan usaha kemudian semata2 akan jatuh sekali dan sendiri atas orang2 juga yang kepala membawa hal itu. Maka itulah kepada orang2 sebagian tiada patut diluluskan yang mencahari saja daya peliharanya daripada bicara2 perbantahan, maka itu juga kepada orang2 itu boleh dipikir mereka itu ada punya faedah pada hal melebihkan pekerjaan 2 landrad adanya. 
Based on the examples in the table above, we found the word bicara was used to translate at least five English words, such as "fact", "case", "cause", "suit" or "litigation". In the Naskah Kitab Hukum manuscript, the word bicara which was used to translate the word "fact" appears two times; to the word "case", 15 times; to the word "cause", 13 times; to the word "suit", eight times and to the word "litigation", one time. In addition, the word bicara was also used to form a number of terms in the legal field, such as rumah/tempat bicara (the court), lawan bicara (the parties), (orang) yang alah/hilang bicara (the loser of the suit), kepala bicara (the president of court) and surat2 bicara (the proceedings).

In the second decade of the 19th century, the word bicara was commonly used by Malay speaker; one proof is that word was contained as an entry in the MalayEnglish dictionaries. In Marsden (1812, 37), for example, the word bicara has six meanings, one of which is "suit, cause". The word bicara, with the first consonant sound changes so that it becomes wicara, was also contained in the JavaneseDutch dictionaries. In fact, in Gericke and Roorda $(1847,390)$ as well as Roorda $(1875,515-516)$, it was expressly stated that the word wicara was a variation of the Malay bicara. These two words - bicara and wicara - come from the Sanskrit. In addition, for Austronesian languages, the sound change [b] to [w], as well as the sound [p] to [f], was natural so it is called the natural sound change. However, in Sundanese, the bizarre sound change often occurs, where the sound [b] or [w] actually changes to [c] or [nc], such as beringin $\rightarrow$ caringin (banyan, Ficus spp.), sawa $\rightarrow$ sanca (python), ketumbar $\rightarrow$ katuncar (coriander seed) and kawah $\rightarrow$ kancah (vat, cauldron) (Blust 2005, 220, 238).

The word wicara which means "case, cause and suit" apparently had been used by Javanese speakers at least since the 17th century. In Article 10 of the "friendship contract" between the Cirebon Sultanate and the VOC dated 4th December 1685 we mentioned earlier, there are the words witjara which means "case, suit or cause" and amitjarakakěn which means "to be handled/to be tried in the court".

\section{Conclusion}

The analysis in previous section shows that Raffles made the Naskah Kitab Hukum manuscript as a means of social engineering to the indigenous people of Java. It could be seen at least on three matters: first, legislation process before the issuing of regulation, second, accommodating the social cohesion of Java inhabitants into the regulation and third, domestication of legal terms in English which were not familiar with the Java inhabitants. 
The legislation process was showed by Raffles' efforts to first visit many areas on Java and then collect very considerable information both from colonial and indigenous officials. Thus, he obtained adequate material to lay the foundations in the issuance of regulations concerning the police and judiciary on Java.

The accommodation was shown by the inclusion of a number of legal and customary rules that have long been applied in Java. In addition, it was shown through the involvement of the penghulu, as the expert of the Islamic and customary laws, in the administration of justice. It was based on the fact that the inhabitants of Java actually had very good legal rules which were the result of a combination of customary laws inherited by ancestors with the Islamic values, although none of those rules were enforced "nationally".

Meanwhile, the domestication was shown by the replacement of the unfamiliar English terms to the terms which were considered friendlier for the indigenous people. It was meant that the inhabitants of Java as the subjects of law. It was intended that the inhabitants of Java, as the subjects of law, genuinely understood well the various rules contained in the regulation while increasing the chances of social engineering towards them, as Raffles' desire.

By publishing the Naskah Kitab Hukum manuscript, Raffles succeeded in implementing a more efficient judicial system on Java and in establishing principles so as to establish a judicial relationship with the indigenous people. It was the fruit of Raffles' hard work in gathering information about the original customs, especially with regard to the judicial system. He also succeeded in inducing the indigenous people to hand all cases to the courts under European influence. Nevertheless, we have not obtained evidence that the rules contained in the Naskah Kitab Hukum manuscript were effectively implemented, moreover not all officials in Java were loyal to him. In addition, the religious leaders on Java continued to oppose the implementation of the European-style justice system and this condition lasted at least until the end of the Java War in 1830. One of the figures who strongly opposed it was Pangeran Diponegoro (1785-1855). He stated that the European government on Java had created enormous misfortune because it alienated Javanese people from the divine law which brought by the Prophet Muhammad. 


\section{References}

Blust, R. 2005. Must sound change be linguistically motivated? Diachronica 22(2): 219269.

Boulger, D.C. 1897. The life of Sir Stamford Raffles. London: Horace Marshall and Son.

Brandes. J. 1894. Eenige officieele stukken met betrekking tot Tjërbon. Tijdschrift voor Indische Taal-, Land-en Volkenkunde XXXVII: 449-488.

Breman, J. 2014. Keuntungan kolonial dari kerja paksa, sistem priangan dari tanam paksa kopi di Jawa, 1720-1870. Jakarta: Yayasan Pustaka Obor Indonesia.

Day, C. 1904. The policy and administration of the Dutch in Java. New York/London: The Macmillan Company.

De Klein, J.W. 1931. Het Preangerstelsel (1677-1871) en zijn nawerking. Delft, The Netherlands: N.V. Technische Boekhandel en Drukkerij J. Waltman Jr.

Gardner, J.A. 1961. The sociological jurisprudence of Roscoe Pound (part I). Villanova Law Review 7(1): 1-26.

Gericke, J.F.C. and Roorda, T. 1847. Javaansch-Nederduitsch woordenboek. Amsterdam: Johannes Müller.

Hazmirullah and Ma'mun, T.N. 2018. Naskah Kitab Hukum Raffles: Sebabak sejarah sistem peradilan di Nusantara. In Naskah Nusantara: Antara kekunoan dan kekinian, eds. A. Gunawan and A. Akbar, 3-28. Jakarta: Masyarakat Pernaskahan Nusantara dan Perpustakaan Nasional.

Isnaeni, H.F. 2015. Sepuluh fakta di balik pembangunan Jalan Daendels dari Anyer ke Panarukan. https://historia.id/kuno/articles/sepuluh-fakta-di-balik-pembangunan -jalan-daendels-dari-anyer-ke-panarukan-6ae2W (accessed 16 October 2018).

Lombard, D. 2008. Nusa Jawa: Silang budaya. Batas-batas pembaratan. Jakarta: Gramedia Pustaka Utama/École française d'Extrême-Orient.

Marsden, W. 1812. Dictionary of the Malayan language. London: Cox and Baylis.

McManaman, L.J. 1958. Social engineering: The legal philosophy of Roscoe Pound. St. John's Law Review 33(1): 1-47.

Pound, R. 1912. The scope and purpose of sociological jurisprudence. Harvard Law Review 25(6): 489-516.

Raffles, T.S. 1830. The history of Java (2nd ed., vol. 1). London: John Murray. 1814a. Naskah kitab hukum. Mss. Eur. D. 742/1, ff. 155-166. The British Library, London. http://www.bl.uk/manuscripts/Viewer.aspx?ref=mss_eur_d742!1_f155r.

1814b. Substance of a minute recorded by the honourable Thomas Stamford Raffles, Lieutenant-Governor of Java and its dependencies, on the 11th February 1814: On the introduction of an improved system of internal management and the establishment of a land rental on the Island of Java. London: Black, Parry and Co. [Printed but not published]

Roorda, T. 1875. Javaansch-Nederduitsch handwoordenboek. Amsterdam: Johannes Müller.

Sastrodinomo, K. 2009. Mil, kilometer dan pal. http://cetak.kompas.com/read/ xml/2009/07/31/03141170/mil.kilometer.dan.pal (accessed 30 July 2017).

Shuttleworth, M. and Cowie, M. 2014. Dictionary of translation studies. London/New York: Routledge. 
Singh, M. 2016. Sociological jurisprudence. http://www.legalservicesindia.com/ article/2190/Sociological-Jurisprudence.html (accessed 21 January 2018).

Soekanto, S. 2016. Pokok-pokok sosiologi hukum. Jakarta: Rajawali Pers.

Thorn, M.W. 2004. Memoir of the conquest of Java. Singapura: Periplus.

Toer, P.A. 2005. Jalan raya pos, Jalan Daendels. Jakarta: Lentera Dipantara.

Venuti, L. 1995. The translator's invisibility: A history of translation. London/New York: Routledge.

Wacks, R. 2012. Understanding jurisprudence: An introduction to legal theory. New York: Oxford University Press. 